COMMENTARY

\section{Seeking food justice and a just city through local action in food systems: Opportunities, challenges, and transformation}

Special JAFSCD Issue

Local Government in Food Systems Work

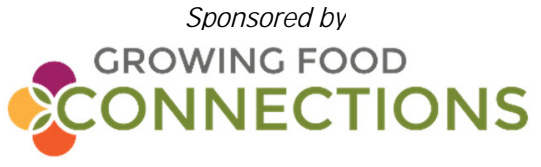

\author{
Jason Reece* \\ The $\mathrm{O}$ hio State University
}

Submitted August 13, 2018 / Revised August 28 and September 9, 2018 / Published online O ctober 17, 2018

Citation: Reece, J. (2018). Seeking food justice and a just city through local action in food systems: O pportunities, challenges, and transformation. Journal of A griculture, F ood Systems, and C ommunity D evelopment, 8(Suppl. 2), 211-215. https:/ / doi.org/ 10.5304/ jafscd.2018.08B.012

Copyright (C 2018 by the Author. Published by the Lyson Center for Civic Agriculture and Food Systems. Open access under CC BY license.

P roducing social change and supporting social justice has always required multiscalar strategy and action. Federal policy actions can be transformative, but are sensitive to extreme philosophical shifts and partisan conflict in federal leadership. When federal leadership is unstable, local and regional government action provides a critical space for maintaining movement forward and presenting opposition when federal policies are not supportive.

These dynamics are evident in many spheres of policy, such as housing, transportation, economic development, education, health, and food systems. We can see this tension in food systems today, as federal policies regarding agricultural subsidies and proposals to tighten food assistance programs (e.g., SNAP) can be in opposition to local goals of supporting sustainable and just local food systems.

* Jason Reece, Ph.D., Assistant Professor, City \& Regional Planning, Knowlton School of Architecture, The O hio State University; 289 Knowlton Hall, 275 West Woodruff Avenue; Columbus, OH 43210-1138 USA; Reece.35@osu.edu
Local activities and practitioners must be agile to work within an ever-changing federal policy landscape.

The long-term trend of federal devolution places even greater emphasis on "going local" to support reforming systems and social change. Discussions of federal versus local action can be overwhelmed by academic debate around the evils of neoliberalism. But for local activists, practitioners and marginalized communities, these theoretical arguments do little to bring change to their communities. Local action remains the primary sphere of influence to support social justice. Local action also is the primary space of innovation, as collaborative local efforts organically evolve and create new models for supporting food justice.

The collection of experiences documented by scholars and practitioners in this special issue of the Journal of A grialture, F ood Systems, and Community D evelopment (JAFSCD) illuminates the opportunities for reshaping food systems through local government action and collaboration. They also demonstrate the persistent challenges facing systemic 
reforms and offer insights from practice that should inform our efforts to produce transformational change in systems. Upon review of these diverse works of scholarship, several themes emerge.

\section{Recognizing the Intrinsic Value of Activist Scholarship}

I am moved by the passion and dedication of the many activist/ practitioner scholars who contributed to this special issue. Activist scholars and practitioners can present a unique and enriching perspective on producing social change while assuring objectivity through disclosure of conflicts of interest and rigorous methods. These scholars deeply inform our collective knowledge, and their contributions should be encouraged by the academy. I am encouraged by venues such as JAFSCD that feature works of activist scholarship. I argue that for the continued evolution toward broader civil rights and justice, activist scholarship is critical to engage, inform, document, and empower social change movements. Scholarship and university resources are critical to support social justice movements and to counter entrenched political and corporate opposition to reforms.

\section{Local City Planning as an 0 pportunity and Obstacle}

City planning stakeholders and processes (such as the comprehensive plan) are identified by multiple authors as critical to moving food system reforms into local policy. The comprehensive plan, and by extension local zoning ordinances, can be powerful tools when structured correctly to position a community to engage food systems. While food systems have not traditionally been a focal point of land use policy, city planning is generally an evolving practice that is open to multidisciplinary perspectives (Friedmann, 2008). Planning will continue to embrace food systems efforts, just as it has evolved to engage emerging issues such as public health, social equity, sustainability, and climate change or resilience. As noted in Rejoining the Planning and Public $\mathrm{H}$ ealth $\mathrm{F}$ ields: $\mathrm{L}$ everaging $\mathrm{C}$ omprehensive Plans to Strengthen Food Systems in an U rban versus Rural Jurisdiction (Mui, Khojasteh, Hodgson, \& Raja, 2018), the built environment is a "unifying issue" for the disciplines of planning and public health. Food system reformers should view planning offices as potential allies to support their efforts and infuse reforms into policy.

While planning can be a pathway to reform, food system actors should be cognizant of the challenges in reforming city planning practices. Planning is a highly political process, not immune to the conflicts that can disable reform in other venues of local government, and the profession has a mixed history of both supporting and impeding social equity goals. This dichotomy is most evident in local government, where local jurisdictions have played the role of both progressive reformer and disenfranchising villain in supporting social justice through land use policy (Reece, 2018). Land use policy and zoning have worked to improve the health, well-being, and quality of life within our cities, but also have been manipulated nefariously to support the goals of social control and segregation of marginalized communities.

Euclidian zoning (which places emphasis on separation of use) is the bedrock of our local land use regulatory system, and this antiquated model of regulation can be a barrier to $21^{\text {st-century planning }}$ goals. In its infancy, zoning was designed to tame the chaos and disorder of the late 19th-century city. As the U.S. Supreme Court notes in the 1926 E uclid v. A mbler Realty decision, urban land use nuisances were often valid activities, but were just located in the wrong location, "like a pig in the parlor instead of the barnyard" (Village of Euclid, O hio v. Ambler Realty Co., 1926).

Thus the separation of land uses through zoning was an appropriate policy solution to address this early $20^{\text {th }}$-century urban challenge. The philosophy of Euclidian zoning is most evident in how zoning has been used historically to disconnect food systems from residential areas and to force the separation of food system functions (e.g., growing, processing, and retailing). As we seek to reform our land use to engage food systems, we must acknowledge systemically the need to reform antiquated land use practices molded by Euclidian zoning. These reforms are critical to meet a number of contemporary challenges, from encouraging physical activity to producing affordable housing and supporting diverse communities. Food system 
reformers should engage with other stakeholders who see reforming land use practice as essential to supporting a more sustainable and just $21^{\text {st.century }}$ city.

\section{The Goldilocks Dilemma: Where Do We Center Reform Efforts?}

Food policy councils face a G oldilocks dilemma, trying to find the delicate balance between government legitimacy and influence while avoiding domination by local government political agendas. As demonstrated by several of the authors in this special issue, shifting local political dynamics can rapidly disrupt or alter progress. Food policy councils must effectively weather these storms while keeping an emphasis on policy advocacy, simultaneously engaging the community and facilitating strong relationships with decision-makers. To achieve these goals, councils must sit in a unique space, not as isolated advocates, but also not as an official arm of government. In essence, food policy councils become their own semi-autonomous "advocacy planner" in the larger planning system, acting as a continual voice of reform in a constantly changing political atmosphere.

\section{Moving Decision-makers: Making the Case through Metrics while Valuing the Relational}

As demonstrated in the case study $T$ he R ole of Metrics in F ood Policy: L essons from a D ecade of $E$ x perienœ in N ew Y ork City (Freudenberg, Willingham, \& Cohen, 2018), food system reform requires clear success metrics to move decision-makers forward. Clear, measurable outcomes that can be tied to evidence-based research are essential to motivate policy-makers, particularly around more abstract concepts such as equity. But, as this and other case studies demonstrate, measures and metrics can be challenging to define, keep consistent among stakeholders, and routinely monitor.

Despite these challenges, food system reform must allocate resources and energy to assuring that success measures can be articulated and documented. While emphasizing hard data and evidence-based research, we cannot forget the power of the relational in driving systemic change, particularly through the lens of collective impact (Kania, Hanleybrown, \& Splansky Juster, 2014).
Relationship-building and a consistent process of co-learning can facilitate transformative ideas and solutions among diverse stakeholders. This messy but important relationship-based process for driving "serendipitous collaboration" (Gupta et al., 2018, p. 19) for food system reform is clearly documented within the case studies.

\section{Equity and Inclusion: Important but Elusive Goals}

All efforts documented in these case studies illustrate the importance of equity and inclusion as foundations of food system reform. Yet achieving equity goals can be elusive and frustrating. Dynamics of systemic inequality, marginalization, and "othering" has a tendency to reemerge within progressive reform movements, a challenge that is seen in the local food systems movement, which is often dominated by a White upper- and middleclass demographic.

This othering can be seen in the article $\mathrm{C}$ ommeraal and $\mathrm{A}$ nti-H unger Sector $\mathrm{V}$ iews on $\mathrm{L}$ ocal $\mathrm{G}$ overnment Strategies for $\mathrm{H}$ elping to $\mathrm{M}$ anage $\mathrm{F}$ ood $\mathrm{W}$ aste ( $\mathrm{O}$ tten, Diedrich, Getts, \& Benson, 2018) as an interviewee refers to individuals seeking food assistance not as individuals, but as the health challenges (diabetics, obese) projected upon them. This lack of cultural understanding and empathy also is reflective of our national dialogue around issues of diet, nutrition, and obesity.

Social determinant and life course research in public health has clearly demonstrated that our overall health is less a reflection of our choices or access to particular types of food, but rather a reflection of deep structural inequalities and the presence or absence of societal privilege. Chronic stress from various forms of discrimination and deprivation over the life course can be more damaging to metabolisms and health outcomes than physical access to fresh food. But rarely are these important dynamics surfaced in our efforts toward food justice. Food justice should not only be about access and nutrition, but also about empowerment and improving the quality of life for marginalized communities.

The various scholars in this special issue routinely acknowledge the inherent challenges in supporting equity, in a food system context that 
includes not only food security, but local empowerment and just wages for food workers. As suggested by Gilbert, Schindel, and Robert (2018) in Just Transitions in a Public School F ood System: The Case of Buffalo, N ew Y ork, we should be dreaming and thinking bigger - we should be concerned not only with access, but with seeking just transformation of our system. Y et to achieve these broad goals, food system reform efforts must become truly diverse and inclusive.

Equity requires replacing tokenism for sustained efforts to open decision-making to those communities most marginalized by the current systems, and if necessary to develop pipelines for leadership development. Any social change effort dominated by White and higher-income practitioners will be undermined by the dynamics of race, class, ethnicity, power, privilege, and bias. This commitment to equity will require time, resources, and a willingness to hand over power by White progressive leaders.

Cultivating leadership is an essential mechanism of power- and resource-sharing, to assure that marginalized communities have the opportunity to be at the forefront of decision-making. It requires the practice of cultural humility and an openness to listen more than lead. Most importantly, it requires an elevation of those most "othered" by the system to equal status within efforts to reform the system.

\section{A Word of Caution: Food System Reform and the Threat of Eco-Gentrification}

Multiple authors acknowledge conflicts in their case studies related to the use of public space for urban food production. I caution that these minor conflicts can also reflect a larger challenge to a just food system movement. Continued urbanization will increase the density of our cities, threatening public spaces, and if not mitigated will result in gentrification in marginalized communities. Food system reforms in urban and metropolitan spaces will also be affected by these dynamics and may unknowingly contribute to gentrification. Practitioners and scholars have acknowledged the threat of urban greening becoming a form of "ecogentrification" (Haffner, 2015). The urban amenities produced by food system reforms can serve the needs of marginalized communities, or they can spur speculative development, rising property values, and displacement.

The difference between these two outcomes depends on how practitioners manage urban food production efforts. Do we fully understand if marginalized communities are empowered to express their positions on whether their community should embrace these local land use changes? As initiatives develop, are marginalized communities authentically engaged and are residents placed in leadership positions? Are changing neighborhood conditions being monitored, and have mitigation efforts been identified to avoid displacement? Are food system reforms tied to other critical needs, such as affordable housing and economic empowerment for marginalized neighborhoods? These are the needs and questions that must be on the agenda for food system reform efforts moving forward.

\section{References}

Freudenberg, N., Willingham, C., \& Cohen, N. (2018). The role of metrics in food policy: Lessons from a decade of experience in New York City. Journal of A griaulture, F ood Systems, and Community D evelopment, 8(Suppl. 2), 191-209. https:// doi.org/ 10.5304/ jafscd.2018.08B.009

Friedmann, J. (2008). The uses of planning theory: A bibliographic essay. Journal of Planning E ducation and Research, 28(2), 247-257. https:/ / doi.org/ 10.1177/ 0739456X 08325220

Gilbert, J., Schindel, A. E., \& Robert, S. A. (2018). Just transitions in a public school food system: The case of Buffalo, New Y ork. Journal of A grialture, F ood Systems, and C ommunity D evelopment, 8(Suppl. 2), 95-113.

https:// doi.org/ 10.5304/ jafscd.2018.08B.011

Gupta, C., Campbell, D ., Sowerwine, J., Munden-Dixon, K., Capps, S. Feenstra, G ., \& van Soelen, K. (2018). Food policy councils and local govemments: Creating effective collaboration for food systems change. Journal of A griculture, F ood Systems, and Community D evelopment, 8(Suppl. 2), 11-28. https:/ / doi.org/ 10.5304/ jafscd.2018.08B.006 
Haffner, J. (2015, May 6). The dangers of eco-gentrification: What's the best way to make a city greener? The $\mathrm{G}$ uardian. Retrieved from https:/ www.theguardian.com/ cities/2015/ may/ 06/ dangers-ecogentrification-best-way-make-citygreener

Kania, J., Hanleybrown, F., \& Splansky Juster, J. (2014). Essential mindset shifts for collective impact. Stanford Social Innovation Review, Fall. Retrieved from https:// ssir.org/ articles/ entry/ essential_mindset_shifts for_collective_impact

Mui, Y., K hojasteh, M., Hodgson, K., \& Raja.. (2018). Rejoining the planning and public health fields: Leveraging comprehensive plans to strengthen food systems in an urban versus rural jurisdiction. Journal of A griaulture, F ood Systems, and Community D evelopment, 8(Suppl. 2), 73-93. https:/ / doi.org/ 10.5304/ jafscd.2018.08B.004

Otten, J., D iedrich, S., G etts, K. and Benson, C. (2018). Commercial and anti-hunger sector views on local government strategies for helping to manage food waste. Journal of A griculture, F ood Systems, and C ommunity D evelopment, 8(Suppl. 2), 55-72. https:/ / doi.org/ 10.5304/ jafscd.2018.08B.002

Reece, J. W. (2018). In pursuit of a twenty-first century just city: The evolution of equity planning theory and practice. Journal of Planning L iterature. Advance online publication. https:/ / doi.org/ 10.1177/ 0885412218754519

Village of Euclid, O hio v. Ambler Realty Co., 272 U.S. 365. (1926). 